\title{
Effects of Post-Weaning Consumption of Soy Isoflavones on Prepubertal and Postpubertal Serum Levels of Some Reproductive Hormones of Male Wistar Rats
}

\author{
Ssimbwa Godfrey¹, Eze Ejike Daniel'1, Sheu Sulaiman Oluwadare², Begumya Yovani ${ }^{1}$ \\ ${ }^{1}$ Department of Physiology, Faculty of Biomedical Sciences, Kampala International University, Kampala, Uganda \\ ${ }^{2}$ Department of Physiology, Faculty of Medicine, Kampala International University, Dar es Salaam, Tanzania \\ Email: daneze4@gmail.com
}

How to cite this paper: Godfrey, S., Daniel, E.E., Oluwadare, S.S. and Yovani, B. (2017) Effects of Post-Weaning Consumption of Soy Isoflavones on Prepubertal and Postpubertal Serum Levels of Some Reproductive Hormones of Male Wistar Rats. Advances in Reproductive Sciences, 5, 1122.

https://doi.org/10.4236/arsci.2017.52002

Received: March 16, 2017

Accepted: May 19, 2017

Published: May 22, 2017

Copyright $(9) 2017$ by authors and Scientific Research Publishing Inc. This work is licensed under the Creative Commons Attribution International License (CC BY 4.0).

http://creativecommons.org/licenses/by/4.0/

\begin{abstract}
Chemically, soy contains a group of phytoestrogens called isoflavones, predominantly genistein and daidzein. The aim of the present study was to determine the effects of post weaning consumption of dietary soy isoflavones on prepubertal and postpubertal serum levels of some reproductive hormones of male Wistar rats. The study involved investigating the effects of different doses of isoflavones in the diet. Male rats were weaned on either soy isoflavone free diet or on isoflavone containing diets, formulated by adding increasing amounts of Novasoy, a commercially available isoflavone supplement to the isoflavone free diet to give varying concentrations of isoflavones. Three isoflavone containing diets were used and these had 74.5, 235.6 and $1046.6 \mathrm{mg}$ total isoflavones $/ \mathrm{kg}$ pelleted diet. These diets represented the isoflavone concentration lower, equal to and more than that found in soy-based infant formulas respectively. The results obtained showed that; administration of low doses soy isoflavones $(74.5 \mathrm{mg} / \mathrm{kg})$ produced significant $(\mathrm{p}<0.05)$ increase in serum Antimullerian Hormone levels both in prepubertal and post pubertal rats, when compared to the control groups. Administration of moderate doses of isoflavones $(235.6 \mathrm{mg} / \mathrm{kg})$ produced significant $(\mathrm{p}<0.05)$ increase in serum levels of Antimullerian Hormone and Inhibin in both prepubertal and post pubertal rats when compared to the control groups. Administration of high doses of isoflavones $(1046.6 \mathrm{mg} / \mathrm{kg})$ produced significant $(\mathrm{p}<0.05)$ increase in serum levels of Inhibin in both prepubertal and post pubertal rats when compared to the control groups. From this study, it was concluded that post-weaning consumption soy isoflavones produced significant changes in
\end{abstract}


serum Inhibin and Antimullerian Hormone both in prepubertal and post pubertal male Wistar rats and the changes were dose dependent.

\section{Keywords}

Post Weaning, Prepubertal Rats, Postpubertal Rats, Isoflavones, Anti-Müllerian, Inhibin

\section{Introduction}

Most babies Worldwide are weaned on soy-based food supplements [1]. Soy Based Infant Formulas (SBIFs) were developed due to the need for a non-milkbased formula alternative for infants with allergy or those intolerant to cow's milk formulas [2]. Soy based infant formula is mostly used because of the essential nutrients it contains such as proteins, iron, vitamin, mineral, electrolytes, 1-methionine, 1-carnitine, taurine and sucrose [3]. In Uganda, exclusive breast feeding rates remain low [4], exemplified by a study done in Wakiso district which showed that approximately $62 \%$ of the mothers introduced soy porridge to their children by the age of 2 - 3 months [5]. Dietary supplements containing high levels of isoflavonoid phytoestrogens are now widely available [6]. Isoflavone usage has increased because of the correlations between the high soy isoflavone levels in Asian diets and the reduced incidence of coronary heart disease as well as prostate, colon and breast cancers which suggest a possible protective effect of isoflavones [7]. Other potential beneficial aspects of soy consumption include the prevention of osteoporosis as well as hormone replacement therapy in menopause [7]. Despite the protective effects of phytoestrogens on the body, several animal studies investigating the safety of soy isoflavone consumption have demonstrated some deleterious effects on reproductive success and health [8]. The effect of isoflavones is dependent on their concentrations, age of the individual and period of exposure [9]. Various studies have been done using different animal models to show the effects of isoflavones on the reproductive parameters, and such effects included; a decrease in plasma levels of testosterone as well as erectile dysfunction in rats [10], glandular metaplasia in prostate and bulbourethral glands as well as gynecomastia in cattle [11], a decrease in litter size and increased post-implantation loss in mice [12]. Exposing female neonatal mice to the synthetic estrogen, ethinylestradiol, caused alteration in Cyst breakdown, oocyte survival and follicle development [13]. A combination of lignan, genistein and daidzein containing diet showed reduced serum estradiol levels in the pregnant rats as well as reduced anogenital distance in the newborn males [14]. While most of the researches focused on assessing the effects of isoflavones on postpubertal parameters, the researches which assess the effects of isoflavones on prepubertal parameters have not been fully demonstrated [15].

This research was therefore aimed at determining the effects of post-weaning consumption of different concentrations of soy isoflavones on the prepubertal 
and post pubertal serum levels of some reproductive hormones of male Wistar rats.

\section{Materials and Methods}

\subsection{Experimental Design}

Forty (40) male Wistar rats of 21 days of age were used. For easy monitoring, adult rats were bred and their off springs were used in the experiment post weaning. The adult rats which were used for breeding were obtained from Mbarara University of Science and Technology, Uganda. Twenty female (25) and ten (10) male rats were obtained for breeding. This research was an experimental study in which rats were fed on diets containing different doses of soy isoflavones post weaning. The experiment was carried out in the Pharmacology laboratory of Kampala International University, Uganda as approved by the animal care committee of the University and according to US Public Health Service Policy on Humane Care and Use of Laboratory Animals; 2001.The experimental diets were formulated at Nuvita Feeds Limited-Jinja (U). Four experimental diets were formulated and these included one which was isoflavone free and three of which contained varying doses of isoflavones that were $74.5 \mathrm{mg}, 235.6 \mathrm{mg}$ and $1046.6 \mathrm{mg}$ per $\mathrm{kg}$ of rat base diet representing low, moderate and high isoflavone doses respectively. These concentrations were in line with those used by [15]. The isoflavone free diet composed of $25 \%$ protein, $05 \%$ fat, $06 \%$ fiber, $08 \%$ total minerals (ash), 11.4\% moisture, $7.0 \%$ total vitamins and the rest being carbohydrates (digestible energy).

The isoflavone containing diets were made by adding different amounts of Novasoy, a commercially available isoflavone concentrate to the base diet. The Novasoy was purchased from Ntinda Shopping Centre, Kampala, Uganda.

At post natal day 22, the experimental rats had their weights taken and were randomly divided in to eight groups, each group containing five rats. The groups were fed on diets containing different doses of isoflavones from postnatal day 22 to post natal day 29. Groups 1 and 5 were fed on isoflavone free diet, groups 2 and 6 were fed on $74.5 \mathrm{mg}$ isoflavones/kg base diet, and groups 3 and 7 were fed on $235.6 \mathrm{mg}$ isoflavones $/ \mathrm{kg}$ base diet while groups 4 and 8 were fed on 1046.6 $\mathrm{mg}$ isoflavones/kg base diet.

The rats in group 1, 2, 3 and 4 were sacrificed on postnatal day 30 representing the prepubertal period while those in group 5, 6, 7 and 8 were sacrificed on postnatal day 45 representing the post pubertal period. The blood samples were collected and then transported under cold chain for hormonal assay. Serum levels of Antimullerian hormone was done by the method previously described by [16] using Antimullerian Hormone enzyme linked immunosorbant assay kit (immunotest material USA). Serum concentrations of inhibin were determined by a method previously described by [17] using Inhibin Gen II ELISA kit. Serum Follicle-Stimulating Hormone (FSH) concentrations were determined by the method previously described by [18] using Microplate Chemiluminescence Immunoassay. Serum Estradiol concentrations were determined by the method 
previously described by [19] using Oxis International, Inc. estradiol kit.

\subsection{Data Analysis}

The means were calculated and written with Standard deviation. Statistical significance analysis across the groups was done using one-way ANOVA at confidence interval of $95 \%$. The statistical significance analysis within the groups was done using t-test.

\section{Results}

\subsection{Serum Levels of Anti-Mullerian Hormone of Prepubertal Rats Fed on Graded Doses of Isoflavones/kg Base Diet}

The serum levels of anti-mullerian hormone (Mean \pm SD) for prepubertal rats were $4.26 \pm 0.054 .28 \pm 0.13,4.54 \pm 0.09$ and $4.24 \pm 0.05 \mathrm{ng} / \mathrm{ml}$ for groups $1,2,3$ and 4 respectively. The results showed that soy isoflavone administration produced a significant increase $(\mathrm{p}<0.05)$ in the serum anti-mullerian hormone level in group 3 (GP3) when compared to the control group (GP1) while group (GP2) and group 4 (GP4) showed a non-significant decrease ( $p>0.05)$ in the serum anti-mullerian hormone levels compared to the control group, as shown in Figure 1.

\subsection{Serum Levels of Inhibin of Prepubertal Rats Fed on Graded Doses of Isoflavones/kg Base Diet}

The serum levels of inhibin (Mean \pm SD) were $58.82 \pm 0.08,58.6 \pm 0.40,60 \pm$ 0.17 and $80 \pm 0.15 \mathrm{pg} / \mathrm{ml}$ for groups 1, 2, 3 and 4 respectively. The results obtained showed that administration of soy isoflavones produced a non-significant decrease ( $p>0.05)$ in the serum inhibin levels in group 2 (GP2) as compared to the control group (GP1) while in group 3 (GP3) and group 4 (GP4), the isoflavone administration caused a significant increase $(p<0.05)$ in serum inhibin levels compared to the control group (GP1), as shown in Figure 2.

\subsection{Serum Levels of Anti-Mullerian Hormone of Post Pubertal Rats Fed on Grade Doses of Isoflavones/kg Base Diet}

The results for serum anti-mullerian hormone levels (Mean \pm SD) for postpubertal rats were $1.700 \pm 0.071,1.840 \pm 0.114,2.080 \pm 1.643$ and $7.440 \pm 0.182$ $\mathrm{ng} / \mathrm{ml}$ for groups 5, 6, 7 and 8 respectively. The results obtained showed a non-insignificant increase $(p>0.05)$ in serum anti-mullerian hormone levels in group 6 (GP6) and 7 (GP7) compared to the control group (GP5) while group 8 (GP8) recorded a significant increase $(\mathrm{p}<0.05)$ in serum anti-mullerian hormone levels compared to the control group (GP5), as shown in Figure 3.

\subsection{Serum Levels of Inhibin Post Pubertal Rats Fed on Grade Doses of Isoflavones/kg Base Diet}

The results for serum inhibin levels (Mean \pm SD) for prepubertal rats were $32.058 \pm 0.025,36.220 \pm 0.078,40.440 \pm 0.134$ and $46.620 \pm 0.517 \mathrm{pg} / \mathrm{ml}$ for 
groups 5, 6, 7 and 8 respectively. The results obtained showed that all groups (GP6, GP7 \& GP8) had significantly increased $(\mathrm{p}<0.05)$ serum inhibin levels compared to the control group (GP5), as shown in Figure 4.

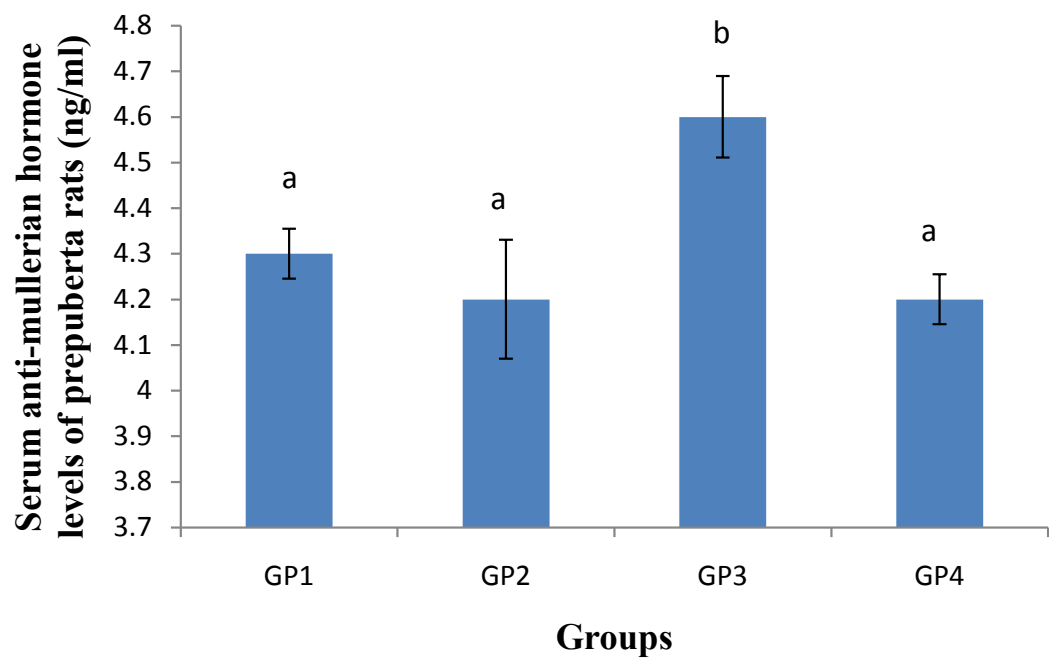

Figure 1. Serum levels of anti-mullerian hormone of prepubertal rats fed on graded doses of isoflavones/kg base diet. Each bar represents a mean of five samples. Bars with the same superscript (a, b, $c$ or d) have no significant differences between them ( $p$ > 0.05). KEY: GP1 $=$ Prepubertal group fed on isoflavone free diet (control); GP2 $=$ Prepubertal group fed on diet containing $74.5 \mathrm{mg}$ isoflavone $/ \mathrm{kg}$ base diet; GP3 = Prepubertal group fed on diet containing $235.6 \mathrm{mg}$ isoflavone $/ \mathrm{kg}$ base diet; GP4 = Prepubertal group fed on diet containing $1046.6 \mathrm{mg}$ isoflavone $/ \mathrm{kg}$ base diet.

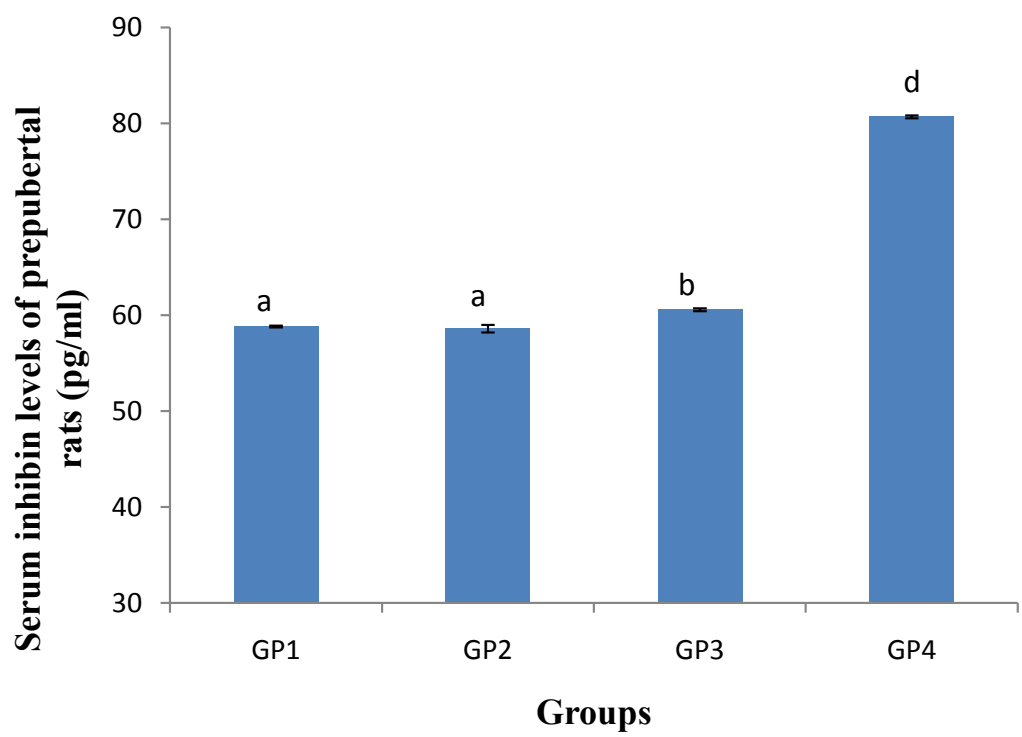

Figure 2. Serum inhibin levels of prepubertal rats fed on graded doses of isoflavones $/ \mathrm{kg}$ base diet. Each bar represents a mean of five samples. Bars with the same superscript ( $a, b, c$ or $d)$ have no significant differences between them ( $p>0.05)$. KEY: $\mathrm{GP} 1=$ Prepubertal group fed on isoflavone free diet (control), GP2 $=$ Prepubertal group fed on diet containing $74.5 \mathrm{mg}$ isoflavone $/ \mathrm{kg}$ base diet, GP3 $=$ Prepubertal group fed on diet containing $235.6 \mathrm{mg}$ isoflavone $/ \mathrm{kg}$ base diet GP4 = Prepubertal group fed on diet containing $1046.6 \mathrm{mg}$ isoflavone $/ \mathrm{kg}$ base diet. 


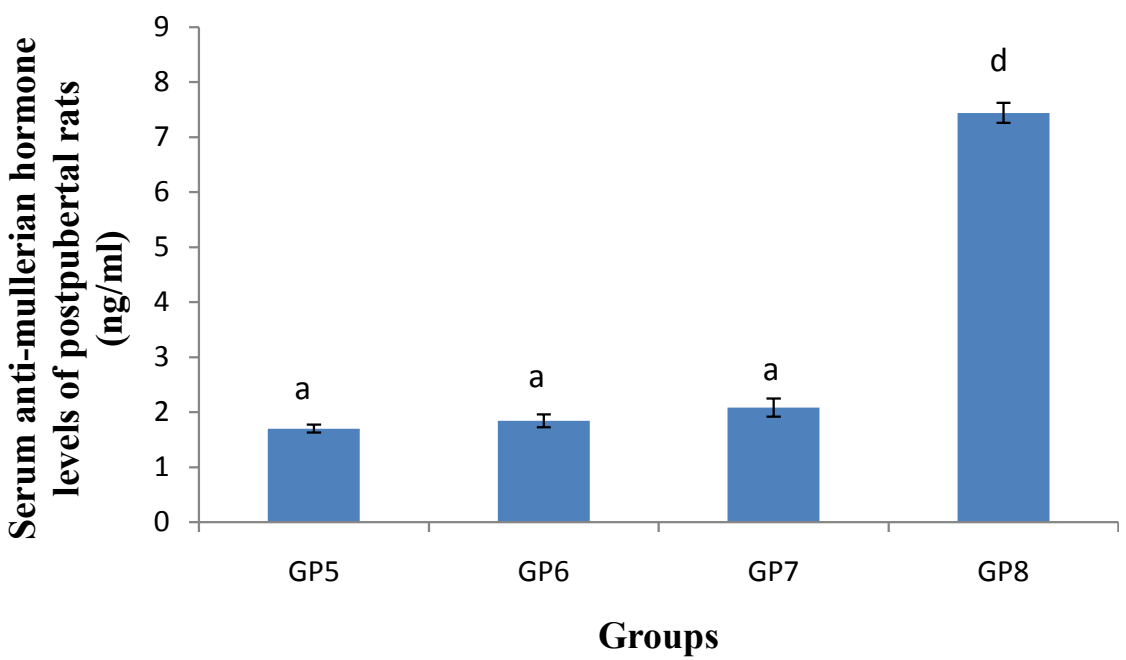

Figure 3. Serum antimullerian hormone levels of post pubertal rats fed on graded doses of isoflavones $/ \mathrm{kg}$ base diet Each bar represents a mean of five samples. Bars with the same superscript ( $a, b, c$ or $d$ ) have no significant differences between them and ( $p>0.05)$. KEY: GP5 = Postpubertal group fed on isoflavone free diet (control), GP6 = Postpubertal group fed on diet containing $74.5 \mathrm{mg}$ isoflavone/kg base diet, GP7 = Postpubertal group fed on diet containing $235.6 \mathrm{mg}$ isoflavone/kg base diet, GP8 = Postpubertal group fed on diet containing $1046.6 \mathrm{mg}$ isoflavone $/ \mathrm{kg}$ base diet.

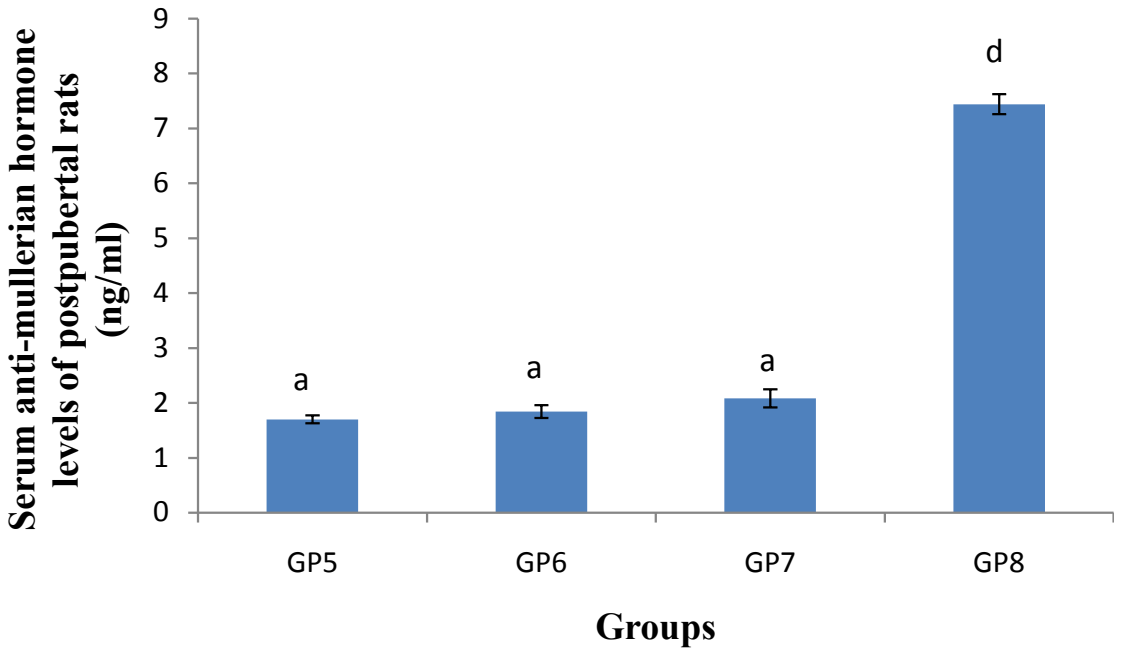

Figure 4. Serum inhibin levels of post pubertal rats fed on graded doses of isoflavones/kg base diet Each bar represents a mean of five samples. Bars with the same superscript ( $a, b$, $c$ or $d$ ) have no significant differences between them ( $p>0.05)$. KEY: GP5 = Postpubertal group fed on isoflavone free diet (control), GP6 = Postpubertal group fed on diet containing $74.5 \mathrm{mg}$ isoflavone/ $\mathrm{kg}$ base diet, GP7 = Postpubertal group fed on diet containing $235.6 \mathrm{mg}$ isoflavone/ $\mathrm{kg}$ base diet, GP8 = Postpubertal group fed on diet containing 1046.6 $\mathrm{mg}$ isoflavone $/ \mathrm{kg}$ base diet.

\subsection{Serum Follicle Stimulating Hormone Levels of Post Pubertal Rats Fed on Grade Doses of Isoflavones/kg Base Diet}

The results for serum follicle stimulating hormone levels (Mean \pm SD) for postpubertal rats were $0.500 \pm 0.000,0.500 \pm 0.000,0.3 \pm 0.000$ and $0.100 \pm 0.000$ IU/L for groups 5, 6, 7 and 8 respectively. The results obtained showed a non- 
insignificant change ( $\mathrm{p}>0.05)$ in serum follicle stimulating hormone levels of group 6 (GP6) when compared to the control group (GP5). However, there were significant decreased $(\mathrm{p}<0.05)$ levels of follicle stimulating hormone in group 7 (GP7) and 8 (GP8) compared to the control group (GP5), as shown in Figure 5.

\subsection{Serum Estradiol Levels Post Pubertal Rats Fed on Grade Doses of Isoflavones/kg Base Diet}

The serum estradiol levels (Mean $\pm \mathrm{SD}$ ) for postpubertal rats were $21.826 \pm$ $0.050,18.068 \pm 0.094,16.052 \pm 0.589$ and $5.012 \pm 0.022 \mathrm{pg} / \mathrm{ml}$ for groups $5,6,7$ and 8 respectively. The results obtained showed that administration of soy isoflavones produced a significantly increased $(\mathrm{p}<0.05)$ serum estradiol levels in all groups (GP6, GP7 \& GP8) compared to the control group (GP5), as shown in Figure 6.

\section{Discussion}

\subsection{Effect of Soy Isoflavone Administration on Serum Anti-Mullerian Hormone Levels of Wistar Rats}

Antimullerian Hormone (AMH) is a peptide belonging to the family of TGFbeta growth factors, the unique effect of which in males is a regression of Mullerian ducts during embryonic development, leading to initiation of a further development towards the male phenotype [20]. In males it is synthesized in Sertoli cells of the testes during embryonic development and then during the whole life. Lower AMH levels than those at the corresponding age are thus a very good marker of central hypogonadism [20]. Low AMH levels are typical for precocious puberty due to inhibitory effect of testosterone, while persisting high AMH

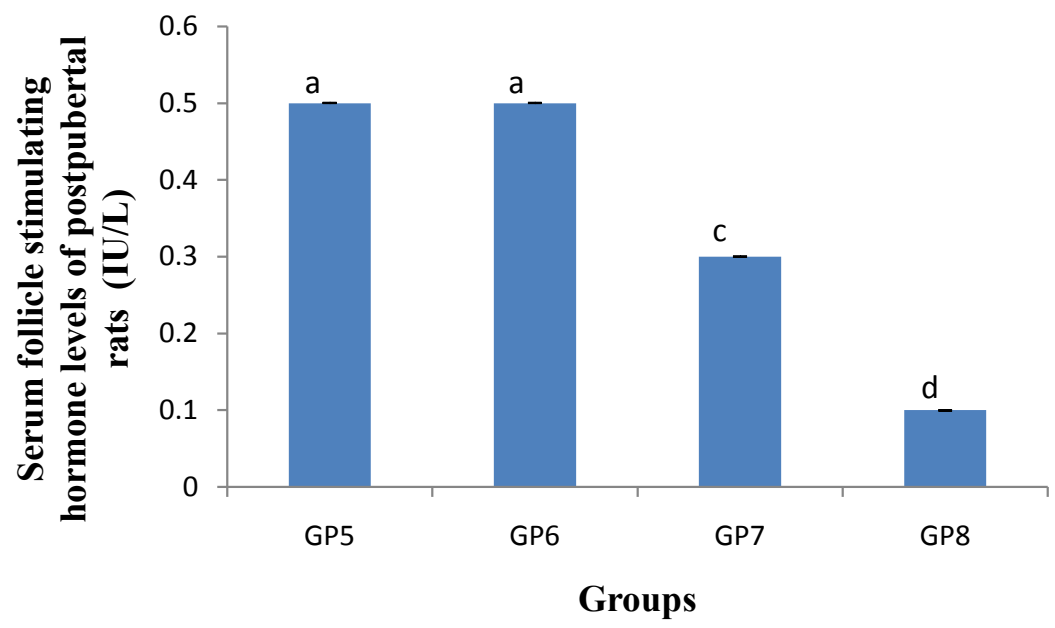

Figure 5. Serum follicle stimulating hormone levels of post pubertal rats fed on graded doses of isoflavones $/ \mathrm{kg}$ base diet. Each bar represents a mean of five samples. Bars with the same superscript $(a, b, c$ or $d)$ have no significant differences between them ( $p>0.05)$. KEY: GP5 = Postpubertal group fed on isoflavone free diet (control), GP6 = Postpubertal group fed on diet containing $74.5 \mathrm{mg}$ isoflavone/kg base diet, GP7 = Postpubertal group fed on diet containing $235.6 \mathrm{mg}$ isoflavone $/ \mathrm{kg}$ base diet, GP8 = Postpubertal group fed on diet containing $1046.6 \mathrm{mg}$ isoflavone/ $\mathrm{kg}$ base diet. 


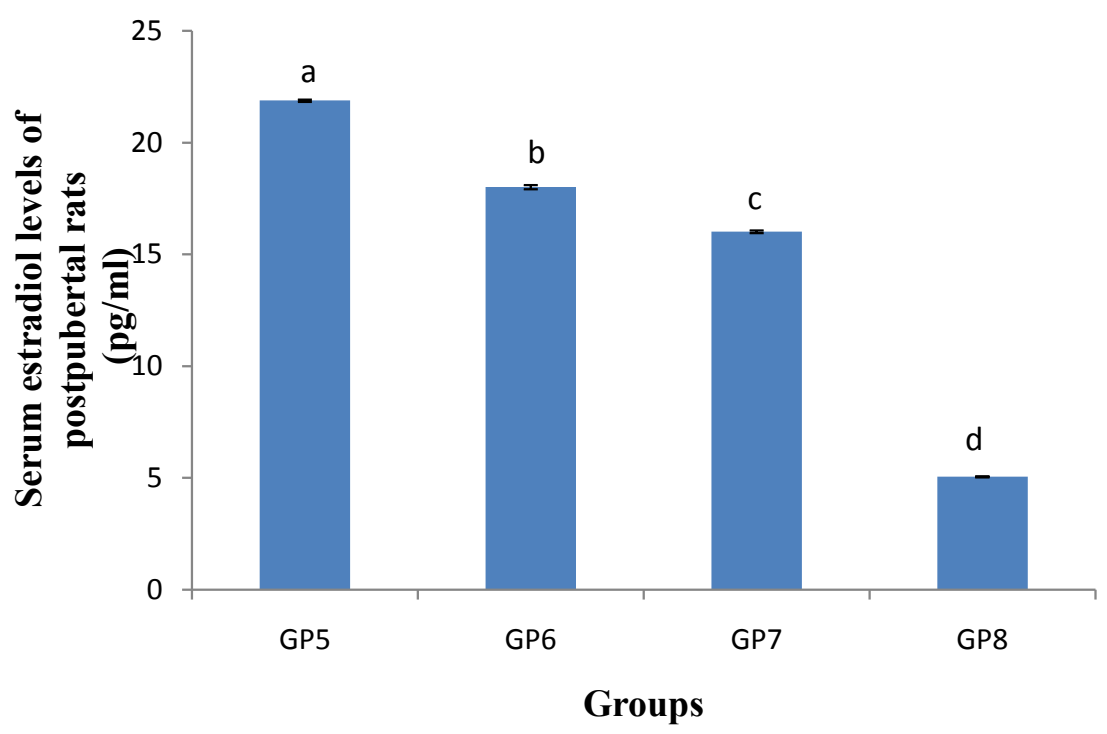

Figure 6. Serum estradiol levels of post pubertal rats fed on graded doses of isoflavones/ $\mathrm{kg}$ base diet Each bar represents a mean of five samples. Bars with the same superscript (a, $b, c$ or $d)$ have no significant differences between them ( $p>0.05)$. KEY: GP5 = Postpubertal group fed on isoflavone free diet (control), GP6 = Postpubertal group fed on diet containing $74.5 \mathrm{mg}$ isoflavone $/ \mathrm{kg}$ base diet, GP7 = Postpubertal group fed on diet containing $235.6 \mathrm{mg}$ isoflavone $/ \mathrm{kg}$ base diet, GP8 = Postpubertal group fed on diet containing $1046.6 \mathrm{mg}$ isoflavone $/ \mathrm{kg}$ base diet.

levels at the age of physiological puberty indicate its delay [21]. In this current study, results obtained showed that administration of moderate doses of soy isoflavones $(235.6 \mathrm{mg} / \mathrm{kg})$ produced a significant $(\mathrm{p}<0.05)$ increase in serum AMH levels, while the low $(74.5 \mathrm{mg} / \mathrm{kg})$ and high $(1046.6 \mathrm{mg} / \mathrm{kg})$ doses of isoflavones produced a non-significant $(\mathrm{p}>0.05)$ decrease in serum AMH levels in prepubertal rats. The results also showed that low $(74.5 \mathrm{mg} / \mathrm{kg})$ and moderate $(235.6 \mathrm{mg} / \mathrm{kg})$ of isoflavones produced a significant $(\mathrm{p}<0.05)$ increase in serum AMH levels while high $(1046.6 \mathrm{mg} / \mathrm{kg})$ produced a non-significant $(\mathrm{p}>0.05)$ increase in serum AMH levels in post pubertal rats. The increased levels of antimullerian hormone might have been due to the stimulatory effect on the Sertoli cells by isoflavones as shown in an in vivo study by [22].

\subsection{Effect of Administration of Soy Isoflavones on Serum Inhibin Levels of Wistar Rats}

Inhibin is a gonadal Dimeric polypeptide hormone that regulates synthesis and secretion of Follicle Stimulating Hormone (FSH) in a negative feedback loop [23]. Inhibin provides negative feedback on FSH secretion, and is an important marker for the functioning of seminiferous tubules due to its production by the Sertoli cells [23]. The gonadal peptide hormone inhibin reflects sertoli cell function. Low inhibin levels have been associated with compromised seminiferous tubule function [16]. The present study showed that low doses of soy isoflavones $(74.5 \mathrm{mg} / \mathrm{kg})$ produced a non-significant $(\mathrm{p}>0.05)$ decrease in serum inhibin levels while moderate $(235.6 \mathrm{mg} / \mathrm{kg})$ and high $(1046.6 \mathrm{mg} / \mathrm{kg})$ doses produced a 
significant $(\mathrm{p}<0.05)$ increase in serum inhibin levels in prepubertal rats.

Results also showed that administration of soy isoflavones produced a significant $(\mathrm{p}<0.05)$ increase in serum Inhibin levels in post pubertal rats. The increased levels of Inhibin might have been due to the stimulatory effect on the Sertoli cells by isoflavones as shown in an in vivo study by [24].

\subsection{Effect of Administration of Soy Isoflavones on Serum Follicle Stimulating Hormone Levels of Wistar Rats}

Follicle stimulating hormone (FSH) is a heterodimeric pituitary glycoprotein which helps to regulate gonadal function in both male and female [25]. In males, FSH stimulates Sertoli cell proliferation and function [25]. It shares with testosterone in the initiation and maintenance of spermatogenesis. Several researchers reported the positive outcome of FSH therapy on sperm quality and fertilizing capability, sperm production and enhancement in conception rate after gamete micromanipulation [26]. The present study showed that low $(74.5 \mathrm{mg} / \mathrm{kg})$ doses of soy isoflavones produced a non-significant $(\mathrm{p}>0.05)$ change in serum FSH levels while moderate $(235.6 \mathrm{mg} / \mathrm{kg})$ and high $(1046.6 \mathrm{mg} / \mathrm{kg})$ produced a significant $(\mathrm{p}<0.05)$ decrease in serum FSH levels in post pubertal rats. These findings support the observations made by [27] which reported decreased serum FSH levels with soy isoflavone administration. However, the findings disagree with those reported in the previous study by [28] that recorded increased serum FSH levels. The decrease in the serum FSH levels in the current study might have been due to the high levels of inhibin that imposes a negative feedback on FSH secretion as reported by [29].

\subsection{Effects of Soy Isoflavone Administration on Serum Estradiol Levels of Wistar Rats}

Testosterone works with estrogen to regulate reproductive behaviors that lead to copulation [30]. Once released by the testes, testosterone is converted by the aromatase enzyme into estradiol, which then acts similarly in its effects on male behavior [31]. High concentrations of estrogen can also inhibit testosterone production through feedback loops and prevent successful copulation in males [31]. The present study showed that soy isoflavone administration produced a significant $(\mathrm{p}<0.05)$ increase in serum estradiol levels in post pubertal rats. The estradiol levels decreased with increase in doses of soy isoflavones consumed. These findings support those observed in the previous studies which recorded a decrease in serum estradiol levels with isoflavone consumption [32].

The reduced estradiol levels might have been due to the inhibitory effects of isoflavones on enzymes such P450 aromatase that converts testosterone to estrogen [33].

\section{Conclusion}

From this study, it may be concluded that post weaning consumption of low $(74.5 \mathrm{mg} / \mathrm{kg})$, moderate $(235.6 \mathrm{mg} / \mathrm{kg})$ and high $(1046.6 \mathrm{mg} / \mathrm{kg})$ doses of soy 
isoflavones soy isoflavones produced significant $(\mathrm{p}<0.05)$ increase in the circulating levels of antimullerian hormone and Inhibin in the prepubertal and post pubertal male Wistar rats. Post weaning consumption of low $(74.5 \mathrm{mg} / \mathrm{kg})$, moderate $(235.6 \mathrm{mg} / \mathrm{kg})$ and high $(1046.6 \mathrm{mg} / \mathrm{kg})$ doses of soy isoflavones soy isoflavones produced significant $(\mathrm{p}<0.05)$ decrease in circulating levels of follicle stimulating hormone and estradiol of post pubertal rats.

\section{Acknowledgements}

The authors would like to thank Kampala International University Management for funding this research. The authors would also like to thank Ms. Winnie Kibuuka and Ms. Winnie Nakakande of the Lubaga Hospital, Kampala, Uganda for their technical assistance towards ensuring that this research study was completed in good time.

\section{References}

[1] WHO/UNICEF (2003) Global Strategy for Infant and Young Child Feeding. WHO, Geneva, 5-10.

[2] Ter Veld, M.G.R., Zawadzka, E., Rietjens, I.M.C.M. and Murk, A.J. (2009) Estrogenicity of Food-Associated Estrogenic Compounds in the Fetuses of Female Transgenic Mice upon Oral and IP Maternal Exposure. Reproductive Toxicology, 27, 133-139.

[3] Dinsdale, B.E.C. (2011) Transgenerational Effects of Early Exposure to Soy Isoflavones on Reproductive Health and Bone Development in CD-1 Mice. Nutritional Sciences, 4, 23-57.

[4] Wamani, H., Tylleskar, T., Astrom, A.N., Tumwine, J.K. and Peterson, S. (2004) Household Assets or Land Ownership Is the Best Predictor of Child Health Inequalities in Rural Uganda. International Journal for Equity in Health, 3, 9. https://doi.org/10.1186/1475-9276-3-9

[5] Ssemukasa, E.L. and Kearney, J. (2014) Complementary Feeding Practices in Wakiso District of Uganda. African Journal of Food Agriculture, Nutrition and Development, 4, 9086-9100.

[6] Boberg, J., Mandrup, K.R., Jacobsen, P.R., Isling, L.K., Hadrup, N., Berthelsen, L. and Nellemann, C. (2013) Endocrine Disrupting Effects in Rats Perinatally Exposed to a Dietary Relevant Mixture of Phytoestrogens. Reproductive Toxicology, 40, 4151.

[7] Paterni, I., Granchi, C., Katzenellenbogen, J.A. and Minutolo, F. (2014) Estrogen Receptors Alpha (ER $\alpha$ ) and Beta (ER $\beta$ ): Subtype-Selective Ligands and Clinical Potential. Steroids, 90, 13-29.

[8] Patisaul, H.B., Mabrey, N., Adewale, H.B. and Sullivan, A.W. (2014) Soy But Not Bisphenol A (BPA) Induces Hallmarks of Polycystic Ovary Syndrome (PCOS) and Related Metabolic Co-Morbidities in Rats. Reproductive Toxicology, 49, 209-218.

[9] Chalabi, S., Al-wattar, Y. and Algalili, I. (2012) Anti-Mullerian Hormone Is a Significant Marker for Male Infertility. Tikrit Journal of Pharmaceutical Sciences, 8, $1-5$.

[10] Kim, S.H. and Park, M.J. (2012) Effects of Phytoestrogen on Sexual Development. Koreanpediat, 55, 265-271.

[11] Hess, R.A. and Carnes, K. (2004) The Role of Estrogen in Testis and the Male Re- 
productive Tract: A Review and Species Comparison. Animal Reproduction, 7, 530 .

[12] Lewis, J.G., Nakajin, S., Ohno, S., Warnock, A., Florkowski, C.M. and Elder, P.A. (2005) Circulating Levels of Isoflavones and Markers of 5-Reductase Activity Are Higher in Japanese Compared with New Zealand Males : What Is the Role of Circulating Steroids in Prostate Disease ? Steroids, 70, 974-979.

[13] Karavan, J.R. and Pepling, M.E. (2012) Effects of Estrogenic Compounds on Neonatal Oocyte Development. Reproductive Toxicology, 34, 51-56.

[14] McCarver, G., Bhatia, J., Chambers, C., Clarke, R., Etzel, R., Foster, W., Hoyer, P., Leeder, J.S., Peters, J.M., Rissman, E., Rybak, M. and Sherman, C. (2011) NTPCERHR Expert Panel Report on the Developmental Toxicity of Soy Infant Formula. Reproductive Toxicology, 92, 421-468.

[15] McVey, M.J., Cooke, G.M. and Curran, I.H. (2004) Increased Serum and Testicular Androgen Levels in F1 Rats with Lifetime Exposure to Soy Isoflavones. Reproductive Toxicology, 18, 677-685.

[16] Hampl, R., Šnajderová, M. and Mardešić, T. (2011) Antimüllerian Hormone Not Only a Marker for Prediction of Ovarian Reserve. Physiological Research, 60, 217 223.

[17] Afzalzadeh, M.R., Ahangarpour, A., Amirzargar, A. and Varnamkhasti, M.K. (2015) The Effect of Vitisvinifera Juice on Serum Levels of Inhibin B, Sperm Count in Adult Male Rats. The World Journal of Men's Health, 33, 109-116. https://doi.org/10.5534/wjmh.2015.33.2.109

[18] Chada, M.Š.R.P.R.Ů., Bronský, J., Kotaška, K., Šídlová, K., Pechová, M. and Lisá, L. (2003) Changes in Serum Levels of Inhibin B, Follicle Stimulating Hormone, Luteinizing Hormone and Testosterone during Childhood and Puberty in Males. Physiotherapy Research, 52, 45-51.

[19] Chimento, A., Sirianni, R., Casaburi, I. and Pezzi, V. (2014) Role of Estrogen Receptors (ERs) and G Protein-Coupled Estrogen Receptor ( GPER ) in Regulation of Hypothalamic-Pituitary-Testis Axis and Spermatogenesis. Frontiers in Endocrinology, 5, 1-13. https://doi.org/10.3389/fendo.2014.00001

[20] Grinspon, R.P. and Rey, R.A. (2010) Anti-Müllerian Hormone and Sertoli Cell Function in Paediatric Male Hypogonadism. Hormone Research in Paediatrics, 73, 81-92. https://doi.org/10.1159/000277140

[21] Wistuba, J., Brinkworth, M.H., Schlatt, S., Chahoud, I. and Nieschlag, E. (2003) Intrauterine Bisphenol A Exposure Leads to Stimulatory Effects on Sertoli Cell Number in Rats. Environmental Research, 91, 95-103.

[22] Ali Ahmed, G., Ghaffoori Hasan, H. and Omer Rashid, A. (2012) Serum Levels of Male Oligospermia Glycoconjugate Inhibin B Hormone and $\alpha$-L-Fucose in Kurdistanipopulations. International Journal of Basic \& Applied Sciences, 12, 59-64.

[23] Jensen, T.K., Andersson A.M., Hjollund, N.H., Scheike, T., Kolstad, H. and Giwercman, A. (1997) Inhibin B as a Serum Marker of Spermatogenesis: Correlation to Differences in Sperm Concentration and Follicle-Stimulating Hormone Levels. The Journal of Clinical Endocrinology \& Metabolism, 82, 4059-4063.

[24] Salama, N. and El-Sawy, M. (2013) Isolated Low Follicle Stimulating Hormone (FSH) in Infertile Males. Urology \& Andrology, 85, 118-122.

[25] Selice, R., Garolla, A. and Pengo, M. (2011) The Response to FSH Treatment in Oligozoospermic Men Depends on FSH Receptor Gene Polymorphisms. International Journal of Andrology, 34, 306.

https://doi.org/10.1111/j.1365-2605.2010.01086.x 
[26] Glover, A. and Assinder, S.J. (2006) Acute Exposure of Adult Male Rats to Dietary Phytoestrogens Reduces Fecundity and Alters Epididymal Steroid Hormone Receptor Expression. Journal of Endocrinology, 189, 565-573. https://doi.org/10.1677/joe.1.06709

[27] Al-Yawer, M.A. (2011) Histological, Histochemical and Biochemical Study of Herbs Containing Phytoestrogens on Rat Testis. The Iraqi Postgraduate Medical Journal, 10, 562-572.

[28] Chong, Y.H., Pankhurst, M.W. and McLennan, I.S. (2015) The Daily Profiles of Circulating AMH and INSL3 in Men Are Distinct from the Other Testicular Hormones, Inhibin B and Testosterone. PLoS ONE, 10, 133-137. https://doi.org/10.1371/journal.pone.0133637

[29] Basu, A., Seth, S., Arora, K. and Verma, M. (2015) Evaluating Estradiol Levels in Male Patients with Colorectal Carcinoma. Journal of Clinical and Diagnostic Research, 9, 8-10.

[30] Hayes, T.B., Anderson, L.L., Beasley, V.R., de Solla, S.R., Iguchi, T., Ingraham, H., Kestemont, P., Kniewald, J., Kniewald, Z., Langlois, V.S., Luque, E.H., McCoy, K.A., Muñoz-de-Toro, M., Oka, T., Oliveira, C.A., Orton, F., Ruby, S., Suzawa, M., Tavera-Mendoza, L.E., Trudeau, V.L., Victor-Costa, A.B. and Willingham, E.. (2011) Demasculinization and Feminization of Male Gonads by Atrazine. The Journal of Steroid Biochemistry and Molecular Biology, 127, 64-73.

[31] Miyata, S. and Kubo, T. (2000) In Vitro Effects of Estradiol and Aromatase Inhibitor Treatment on Sex Differentiation in Xenopuslaevisgonads. General and Comparative Endocrinology, 119, 105-110. https://doi.org/10.1006/gcen.2000.7497

[32] Johnston, I. (2003) Phytochem Functional Foods. CRC Press Incorporated, Boca Raton, 66-68.

[33] Johnston, I. (2003) Phytochem Functional Foods. CRC Press Incorporated, 3, 66-68.

Scientific Research Publishing

\section{Submit or recommend next manuscript to SCIRP and we will provide best} service for you:

Accepting pre-submission inquiries through Email, Facebook, LinkedIn, Twitter, etc. A wide selection of journals (inclusive of 9 subjects, more than 200 journals)

Providing 24-hour high-quality service

User-friendly online submission system

Fair and swift peer-review system

Efficient typesetting and proofreading procedure

Display of the result of downloads and visits, as well as the number of cited articles

Maximum dissemination of your research work

Submit your manuscript at: http://papersubmission.scirp.org/

Or contact arsci@scirp.org 